\title{
PENGUKURAN TINGKAT MINAT DENGAN BAKAT MAHASISWA PENDIDIKAN OLAHRAGA UNIVERSITAS MUHAMMADIYAH SURAKARTA
}

\author{
Pungki Indarto ${ }^{1}$, Nur Subekti ${ }^{2}$, Eko Sudarmanto ${ }^{3}$ \\ ${ }^{123}$ Program Studi Pendidikan Olahraga, Universitas Muhammadiyah Surakarta, Surakarta, Indonesia \\ *pi311@ums.ac.id
}

(Received: August 2018 / Revised: September 2018 / Accepted: September 2018)

\begin{abstract}
ABSTRAK : Penelitian ini bertujuan untuk mengetahui kesesuain minat dengan bakat olahraga pada mahasiswa Pendidikan Olahraga Fakultas Keguruan dan IImu Pendidikan Universitas Muhammadiyah Surakarta tahun 2018. Penelitian ini menggunakan metode survey dan tes. Dengan jenis data kuantitatif, dengan variable 1 data terikat berupa minat dengan bakat olahraga mahasiswa. Populasi mahasiswa Pendidikan Olahraga FKIP UMS berjumlah 229 tahun 2018. Sampel penelitian ini berjumlah 100 mahasiswa dengan teknik pengambilan sampel Purposive Sampling dimana pengambilan sampel dari populasi sesuai yang dikehendaki peneliti. Instrument yang digunakan dalam penelitian ini adalah metode angket dan sport search. Hasil penelitian adalah kesesuaian minat dangan bakat pada mahasiswa Pendidikan Olahraga FKIP UMS tahun 2018 yaitu, olahraga beregu yang sesuai minat dengat bakat sebanyak 14.03\%, olahraga aquatic yang sesuai minat dengat bakat sebanyak $2,7 \%$, olahraga individu yang sesuai minat dengat bakat sebanyak $1.84 \%$, olahraga beladiri yang sesuai minat dengat bakat sebanyak $0.9 \%$, olahraga raket yang sesuai minat dengat bakat sebanyak $1.08 \%$, olahraga atletik yang sesuai minat dengat bakat sebanyak $0.45 \%$.

KATA KUNCI : Minat, Bakat Olahraga, Mahasiswa Olahraga.
\end{abstract}

ABSTRACTS : This research aims to investigate the relationship between interest and talent on sports among student of physical education department of Universitas Muhammadiyah Surakarta. This research used survey and test methods. Given the quantitative data type, variable 1 data-bond used as student's talent and interest on sports. The population of this research is the students of Sport Department of the Faculty of Education and Teacher Training of Universitas Muhammadiyah Surakarta. The sample used in this research were 100 students, with the purposive sampling in which the sampling and population of the research depend on the desire of the researcher. The research instrument being used were questionnaire and sport search. The result of this research is the appropriateness between the talent and the interest of Pendidikan Olahraga FKIP UMS 2018 in group sport 14.03\%, aquatic 2,7\%, individual 1.84\%, self defence $0.9 \%$, racket $1.08 \%$, athletic $0.45 \%$.

KEYWORD (10 Bold): interest, sports talent, sport students.

\section{PENDAHULUAN}

Minat merupakan momen dan kecenderungan yang searah secara intensif kepada suatu objek yang dianggap penting. Kartini Kartono (1996: 12). Minat olahraga berarti kecenderungan seseorang untuk memilih cabang olahraga yang menjadi keinginanya yang dilakukan secara terus menerus untuk mencapai tujuan, sedangkan Bakat adalah potensi yang dimiliki oleh seseorang untuk berprestasi dalam kegiatan atau cabang olahraga tertentu (Singgih dalam Santoso, 2012: 40).

Olahraga memiliki peranan penting dalam kehidupan manusia. Era informasi dan teknologi olahraga berkembang menjadi suatu komoditi ekonomi dan industri. Prestasi puncak ( peak performent) diperoleh dari pembinaan bakat olahraga yang baik, dikatakan baik apabila pemilihan minat kecabangan olahraga sesuai dengan keberbakatan seseorang, sehingga dalam pembinaanya dapat dilakukan secara efektif. 
Perkembangan ilmu dan teknologi dewasa ini khususnya dibidang keolahragaan, telah mengalami kemajuan yang sangat pesat. Oleh karena itu perlu dilakukan beberapa upaya pembinaan dan pengembangan di bidang olahraga, dengan tujuan untuk mencapai prestasi yang optimal pada suatu kejuaraan baik di tingkat nasional maupun regional. Agar mencapai prestasi olahraga tidak lepas dari pendekatan ilmiah, adanya sarana dan prasarana yang menunjang dan membuat metode latihan yang tepat. Pendekatan ilmiah dan pengembangan pencapaian prestasi olahraga, dilakukan karena dengan pengetahuan ilmiah diharapkan dapat membantu memecahkan permasalahan yang berkaitan dengan kepelatihan.

Fasilitas olahraga berpengaruh langsung terhadap peminatan terhadap olahraga, sedangkan sistem pengelolaan dari program keolahragaan berkaitan dengan keberbakatan olahraga. Minat dan bakat olahraga adalah awal pembinaan kepelatihan. Program studi pendidikan olahraga FKIP UMS telah dibuat system pemilihan minat dan bakat olahraga, hal ini dilakukan untuk memetakan minat dan potensi kecabangan olahraga mahasiswa kearah prestasi.

Untuk mengetahui apa saja minat cabang olahraga yang menjadi pilihan mahasiswa dan apakah sesuai cabang olahraga yang dipilih dengan potensi bakat mahasiswa, maka perlu dilakukan suatu penelitian dan bentuk tes. Sebanyak 100 mahasiswa pendidikan olahraga FKIP UMS tahun 2018 menunjukkan pilihan minat cabang olahraga sebagai berikut; sepakbola, futsal, pencak silat, taekwondo, badminton, basket, lari sprint, tolak peluru, lompat jauh, renang, panahan, tenis meja, tenis lapangan.

Penelitian ini dilakukan untuk memperoleh gambaran serta pemetaan antara minat dengan bakat mahasiswa pada awal semester untuk kemudian dilakukan pembinaan minat bakat olahraga secara intensif kearah prestasi.

\section{METODE PENELITIAN}

Penelitian yang dilakukan merupakan penelitian kuantitatif dengan metode survey dan tes. Untuk desain penelitian dapat dijelaskan sebagai berikut :

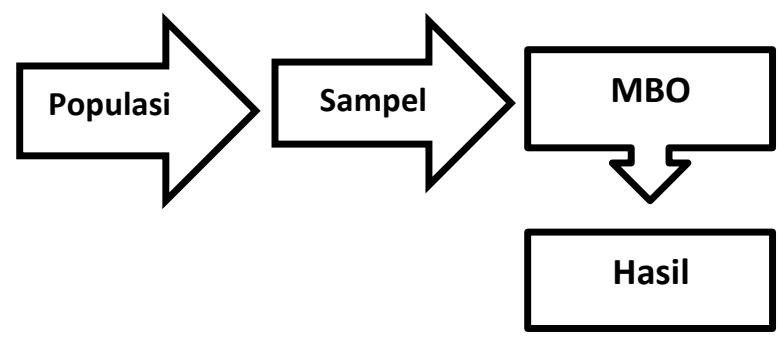

Gambar 1. Desain Penelitian One Shot Case Study (Sugiono. 2012)

Penelitian ini menggunakan satu variable saja yaitu, variable terikat minat bakat olahraga mahasiswa pendidikan olahraga FKIP UMS tahun 2018. Sedangkan populasi dalam penelitian ini adalah seluruh mahasiswa pendidikan olahraga FKIP UMS tahun 2018. Sampel penelitian ini berjumlah 100 mahasiswa teknik pengambilan sampling Purposive Sampling merupakan teknik penentuan sempel dengan pertimbangan khusus sehingga layak dijadikan sempel (Sugiyono 2010:217). Instrument yang digunakan dalam penelitian ini adalah metode angket dan tes sport search. Untuk mengetahui minat mahasiswa menggunakan metode angket, metode angket adalah sejumlah pertanyaan tertulis yang digunakan untuk memperoleh informasi dari responden tentang dirinya Arikunto 2006 : 151 ). Jenis kuisioner yang digunakan dalam peneliti ini adalah angket tertutup, angket yang sudah tersedia alternatif jawaban yang harus dipilih responden. Pengambilan data dilakukan 2 kali untuk setiap responden sekali untuk minat olahraga dan sekali untuk bakat olahraga.

Sport search meliputi tes tinggi badan, tes berat badan, tes tinggi duduk, tes rentang lengan, tes lempar tangkap bola, tes lempar bola basket, vertical jump, Multi stage fitness test (MFT) M. Furqon \& Muchsin Doewes (1999:16). Teknik 
analisis data menggunakan deskriptif kuantitatif prosentase.

\section{HASIL}

Berikut ini adalah hasil survey pilihan minat cabang olahraga mahasiswa pendidikan olahraga FKIP UMS tahun 2018 :

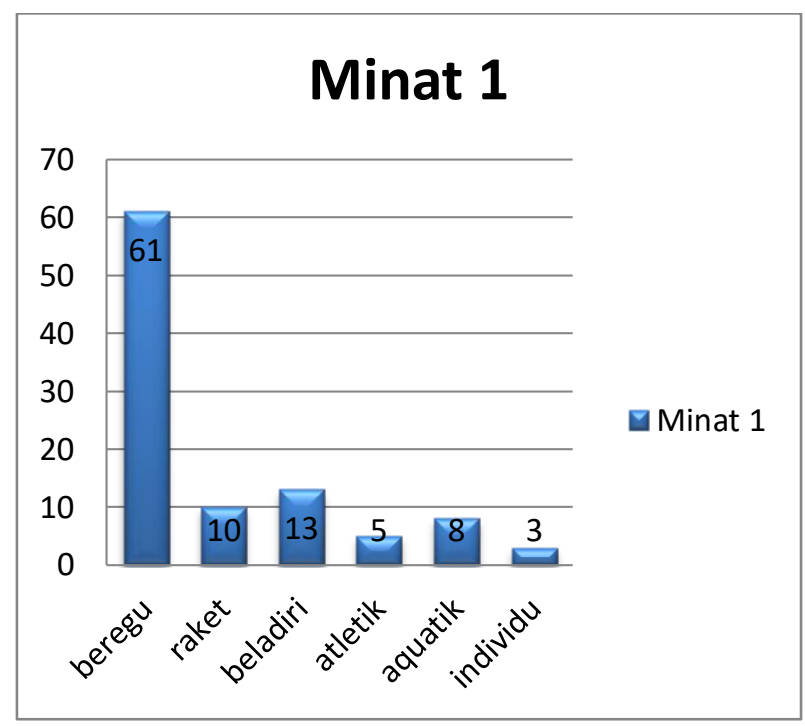

Gambar 2. Klasifikasi Cabang Olahraga Menurut Pilihan Minat Pertama Mahasiswa

Pemilihan cabang olahraga ini diperoleh data sebagai pilihan kedua untuk pembanding pilihan pertama sebagai berikut :

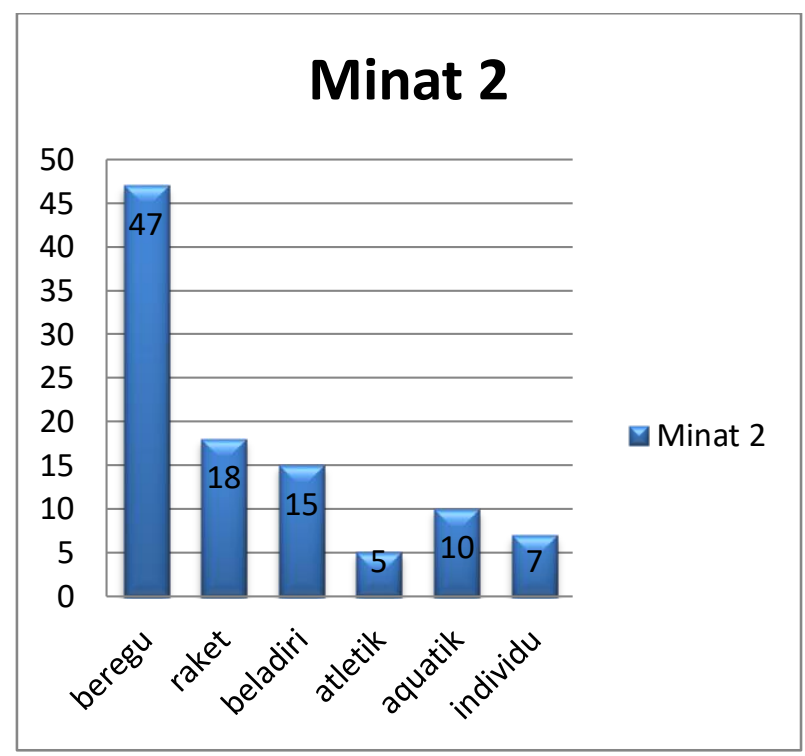

Gambar 3. Klasifikasi Cabang Olahraga Menurut Pilihan Minat Kedua

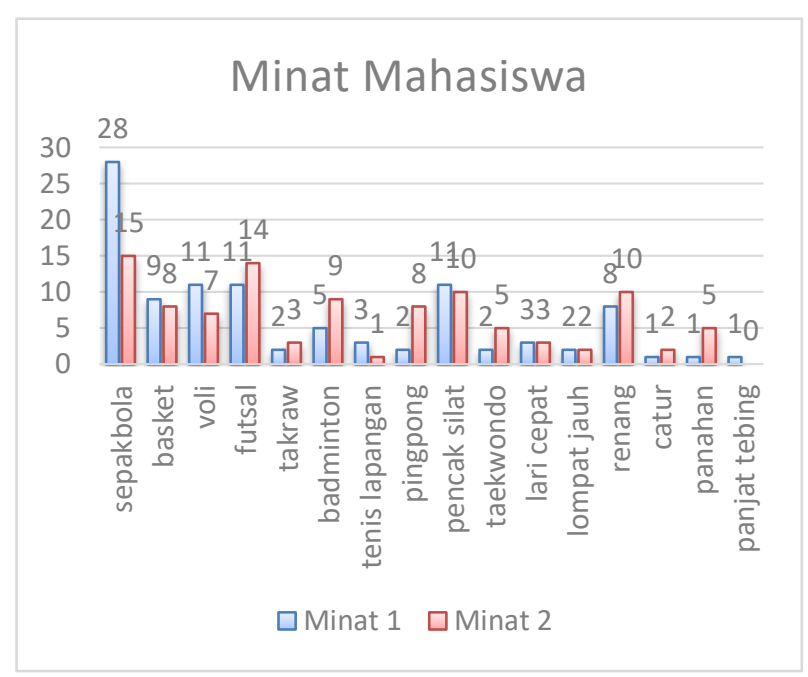

Gambar 4. Minat Mahasiswa Pada Cabang Olahraga Pada Pilihan Satu Dan Dua.

\section{PEMBAHASAN}

Peminatan berdasarkan pilihan cabang olahraga mahasiswa. Berdasarkan hasil survey peminatan pertama mahasiswa terhadap cabang olahraga ada 16 cabang olahraga dapat dijelaskan secara berurutan sebagai berikut; sepakbola $28 \%$, basket $9 \%$, voli $11 \%$, futsal $11 \%$, takraw $2 \%$, badminton $5 \%$, tenis lapangan $3 \%$, pingpong $2 \%$, pencak silat $11 \%$, taekwondo $2 \%$, lari cepat $3 \%$, lompat jauh $2 \%$, renang $8 \%$, catur $1 \%$, panahan $1 \%$, panjat tebing $1 \%$.

Minat pilihan kedua pada mahasiswa terhadap cabang olahraga ada 15 cabang olahraga, dengan demikian terdapat 1 cabang olahraga yang tidak diminati pada pilihan pertama, hasilnya dapat dijelaskan sebagai berikut secara berurutan sepakbola $15 \%$, basket $8 \%$, voli $7 \%$, futsal $14 \%$, takraw $3 \%$, badminton $9 \%$, tenis lapangan $1 \%$, pingpong $8 \%$, pencak silat $10 \%$, taekwondo $5 \%$, lari cepat $3 \%$, lompat jauh $2 \%$, renang $10 \%$, catur $2 \%$, panahan $5 \%$.

Keberbakatan berdasarkan potensi diri mahasiswa. Bakat mahasiswa berdasarkan potensi diri dengan menggunakan tes sport seach secara berurutan sebagai berikut; selam $27 \%$, senam $23 \%$, lompat jauh $9 \%$, tenis lapangan $6 \%$, 
sepakbola $23 \%$, taekwondo $6 \%$, tenis meja $1 \%$, catur $5 \%$.

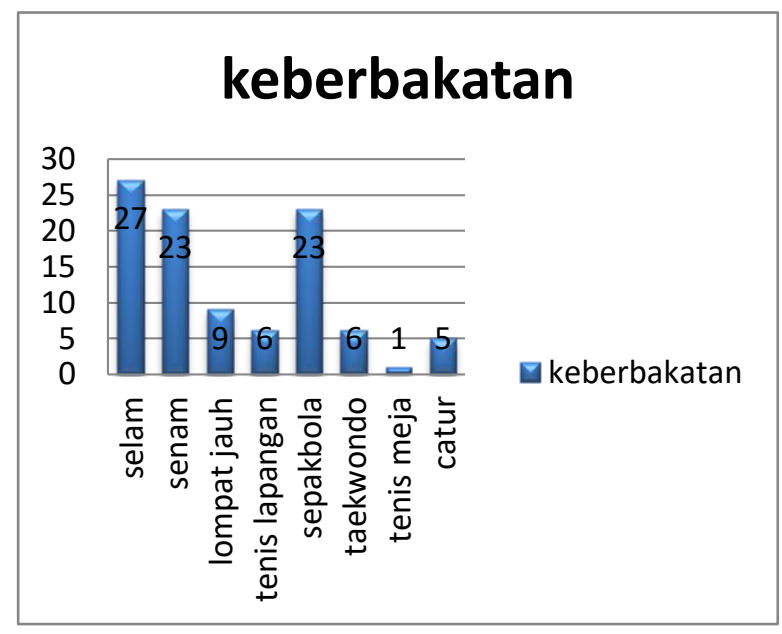

Gambar 5. Hasil Test Keberbakatan Mahasiswa Pada Cabang Olahraga.

Pada hasil tes sport seach keberbakatan diatas dapat diklasifikasikan cabang olahraga ke dalam hasil peminatan mahasiswa pada pilihan satu sebagai berikut;

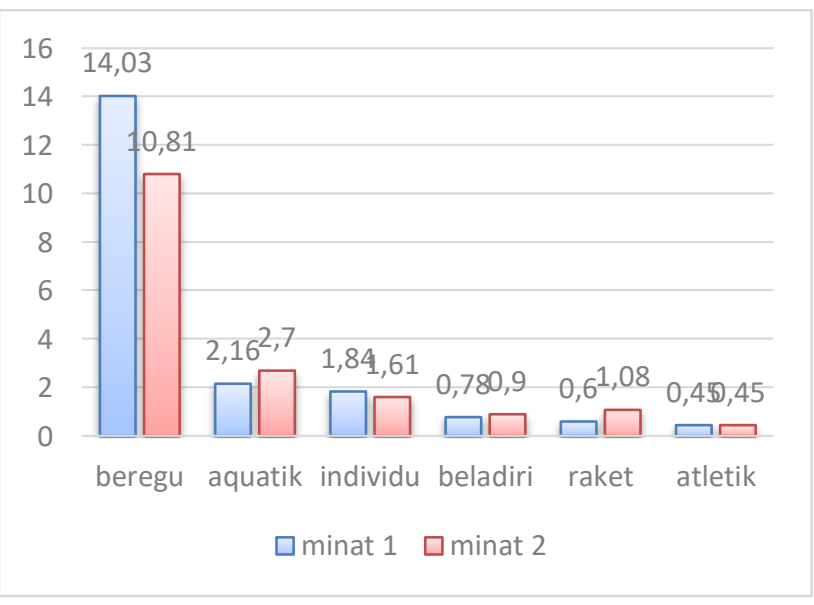

Gambar 6. Kesesuaian Hasil Minat Dengan Bakat Olahraga

Dari gambar di atas dapat di jelaskan terdapat kesesuaian pilihan minat 1 dan 2 secara berurutan terhadap hasil tes keberbakatan mahasiswa Pendidikan Olahraga FKIP UMS tahun 2018 yaitu, cabang olahraga berugu (14.03\% dan $10.81 \%)$, aktifitas aquatic $(2.16 \%$ dan $2.7 \%)$, olahraga individu (1.84\% dan $1.61 \%)$, beladiri
(0.78\% dan $0.9 \%)$, raket (0.6\% dan $1.08 \%$ ), atletik (0.45\% dan $0.45 \%)$. Dari kedua pilihan minat dapat diambil salah satu hasil data kesesuaian yang paling signifikan.

Tabel 1. Tabel Frekuensi Kesesuaian Minat dengan Bakat

\begin{tabular}{llcc}
\hline No & Jenis Olahraga & Prosentase & Frekuensi \\
\hline 1 & Beregu & $14.03 \%$ & 15 \\
\hline 2 & Aquatik & $2.7 \%$ & 3 \\
\hline 3 & Individu & $1.84 \%$ & 2 \\
\hline 4 & Raket & $1.08 \%$ & 2 \\
\hline 5 & Beladiri & $0.9 \%$ & 1 \\
\hline 6 & Atletik & $0.45 \%$ & 1 \\
\hline & Jumlah & $21 \%$ & 24 \\
\hline
\end{tabular}

Dari tabel 1. diperoleh data 24 mahasiswa yang memiliki kesesuaian antara minat dengan bakat, sedangkan sisanya memiliki ketidaksesuaian minat dengan bakat sebanyak 76 mahasiswa

\section{SIMPULAN DAN REKOMENDASI}

PBerdasarkan hasil penelitian dan analisis data yang dilakukan dapat diambil kesimpulan bahwa terdapat kesesuaian minat dan bakat pada mahasiswa Pendidikan Olahraga FKIP UMS tahun 2018 sebanyak $\mathbf{2 1} \%$ dan ketidaksesuaian minat dengan bakat sebanyak $79 \%$.

Data di atas melihat dari potensi mahasiswa dapat diartikan sebagai pemetaan awal kesesuaian minat dengan bakat sebanyak 24 mahasiswa dan ketidak sesuaian minat dengan bakat sebanyak 76 mahasiswa dari beberapa katagori olahraga.

Dari pilihan mahasiswa Pendidikan Olahraga yang paling tinggi tingkat kesesuaianya adalah olahraga beregu dengan $14,03 \%$, hal ini dapat diartikan bahwa olahraga beregu merupakan olahraga yang berpotensi untuk dilakukan pembinaan kearah prestasi. Sedangkan Olahraga atletik memiliki tingkat kesesuaian paling rendah dengan $0.45 \%$, hal ini dapat diartikan bahwa 
olahraga atletik merupakan olahraga yang kurang berpotensi dilakukan pembinaan kearah prestasi.

Pembinaan minat dan bakat mahasiswa Pendidikan Olahraga FKIP UMS tahun 2018 dalam pencapaian prestasi dapat dilakukan secara optimal dan efektif sebaiknya lebih diarahkan pada cabang sepakbola, selam, senam, pencak silat, badminton, dan lompat jauh.

Hasil ini juga dapat digunakan sebagai dasar pemanduan minat dan bakat kearah prestasi kecabangan olahraga pada siswa remaja terutama di perguruan tinggi. Penelitian ini juga dapat digunakan sebagai motivasi dan pemetaan potensi mahasiswa untuk menentukan pembinaan kearah prestasi olahraga.

\section{REFERENSI}

Asdep Pengembangan Tenaga dan Pembinaan Keolahragaan Deputi Bidang Peningkatan Prestasi dan IPTEK Olahraga Kementrian Negara Pemuda dan Olahraga 2007. Pelatihan Pelatih Fisik Level 1.

Hoare,D. (2012). Pengertian identifikasi Bakat. Diperoleh 19 Juli 2018 dari http : //NurulPrihatmokosangjuara.blogspot.co $\mathrm{m} / 2012 / 01 /$ identifikasidanpengembangan bakat.html

Islahuzzaman N. (2010). Identifikasi Bakat Usia Dini Siswa SD-SMP Surakarta.

Jurnal Paedagogia FKIP UNS. (jilid 13, Nomer 1). Hal 61-69.

Mansur. (2011). Pemanduan Bakat Olahraga. Yogyakarta: UNY

M.Furqon H dan Muchsin Doewes. (1999). Pemanduan Bakat Olahraga Model Sport Search. Surakarta: Pusat Pene-litian dan Pengembangan Keolahragaan Universitas Sebelas Maret Surakarta.

Rumini. (2011). Pemanduan Bakat. Universitas Negeri Semarang
Sugiyono. (2012). Metode Penelitian Kuantitatif Kualitatif dan R\&D. Bandung: Alfabeta.

Suharsimi Arikunto. (2010). Prosedur Penelitian Suatu Pendekatan Praktik. Jakarta: Rineka Cipta

Sungkowo, dan Sri Haryono. (2013). "Minat Dan Bakat Siswa SD dan SMP Di Kabupaten Demak Tahun 2014". (Jurnal Media Ilmu Keolahragaan Indonesia). (Volume 3, Nomer 2) 106-113. 